\title{
As contas a bordo da Fragata Sto. António de Taná (1697) UM EXEMPLO DE INTERCÂMBIOS NUM MUNDO GLOBAL
}

\author{
Andreia Martins Torres* \\ andreiatorres@gmail.com
}

RESUMO: O artigo parte da análise das contas encontradas durante a escavação da Fragata Sto. António de Tána, naufragada em Mombaça no ano de 1697, para problematizar sobre o significado da presença destes materiais no contexto das ligações entre a Índia e África. Para tal nos centraremos fundamentalmente em questões comerciais, mas também naqueles conceitos e ideias transmitidos através da cultura material.

PALAVRAS-CHAVE: Contas; Arqueologia Moderna; África.

"Matamingo - Querem alguns, que seja o mesmo que Laqueca. Dizem outros, que Matamingos são a modo de Avellorios, ou coisa que o valha, para Negros”.

Assim é como descreve Rafael Bluteau, no séc. XVIII, um dos tipos de conta que vinha sendo exportado para África pelo menos desde o séc. XVI. Aludindo a vozes populares para justificar um conceito sem nunca referir as características físicas do objecto, trata de o determinar por aproximação a outros que crê semelhantes, definindo-o como uma dessas coisas que usam os negros.

Utilizadas por negros ou por indivíduos de outras "raças", a escavação arqueológica da fragata Santo António de Taná (Quénia) permitiu identificar modelos realizados em vários materiais. Esta embarcação saiu de Goa em 1697, acompanhando um pequeno esquadrão que tinha como objectivo auxiliar o Forte de Mombaça que estava sendo atacado

* Professora da Universidade Nova de Lisboa. Investigadora do Centro de História de Além-Mar da Faculdade de Ciências Sociais e Humanas da Universidade Nova de Lisboa, desde Janeiro de 2010. 
pelos omanitas. O seu destino final era Moçambique mas ela acabaria por naufragar junto à costa no decurso da batalha que colocou fim à presença portuguesa nessa zona (FRAGA, 2008; BLOT, 1984, p. 7; PIERCY, 1978, p. 307; KIRKMAN, 1975, p. 301-319). Os destroços foram recuperados pelas campanhas arqueológicas realizadas, entre 1976-1980, pelo Institute of Nautical Archaeology e o National Museums of Kenya, entre os quais se incluem 39 contas. Estes achados permitiram pôr em valor um conjunto de artefactos que são o reflexo de um modo de viver e das relações comerciais e culturais entre os vários espaços da presença portuguesa.

Desde o início dos intercâmbios entre a Europa e o continente africano que as contas constituíram um elemento privilegiado de troca. O sistema adoptado obedeceu a uma lógica pré-existente onde estes géneros eram abastecidos por muçulmanos. À semelhança do que já sucedia, mas a uma escala muitíssimo maior, ditas mercadorias passaram a integrar as redes de comercio a nível global, circulando por todo o mundo conhecido de então mais além dos limites geopolíticos. Os circuitos que uniam os diferentes entrepostos do Oceano Índico aos do Pacífico e daí com as principais cidades americanas, ou a via Atlântica que punha em contacto a África com Europa e a América, permitiram que, por exemplo, uma "conta chinesa" fosse usada no vice-reino da Nova Espanha.

Em África as contas constaram frequentemente entre a carga embarcada nos navios portugueses destinados ao abastecimento das feitorias. Elas foram usadas como moeda de troca na compra de produtos altamente valorados no mercado europeu e asiático mas, mais que um engano, como normalmente são encaradas pela historiografia contemporânea, elas alcançaram um apreço considerável entre as comunidades autóctones. A quantidade dos exemplares exigidos a cambio desses produtos foi sempre determinada pelas populações africanas que, em ocasiões, as recusaram por não irem de encontro ao seu gosto. Nestes termos, não podemos falar de um comercio desigual, mas de escalas monetárias muito distintas que tornaram determinados negócios vantajosos para ambas partes envolvidas.

Pelos motivos expostos a análise que propomos realizar dos materiais terá em consideração a complexidade da estrutura política da presença portuguesa em África Oriental e no Estado da Índia. Ela proporcionou características únicas de transferências culturais, protagonizadas por estes indivíduos de diferentes origens e etnias, que se 
materializam na coleção em estudo e nos seus possíveis contextos de uso. Em algumas situações, que exporemos mais atentamente, as contas funcionaram como veículo de comunicação, permitindo um diálogo intercultural a nível funcional mas sobretudo simbólico, que teve repercussões em todos os agentes sociais/regionais envolvidos.

Não podemos esquecer o papel importantíssimo de Mombaça, como eixo de ligação precisamente entre a Europa, a Ásia e a África que explica a presença dos vários modelos encontrados. Durante o séc. XVI, saíam todos os anos galeotas desde Diu, Chaul, Damão ou Goa para esta cidade, aproveitando as monções de Janeiro. As mercadorias transaccionadas destinavam-se ao abastecimento do Forte de Jesus, mas sobretudo ao comercio com os Suaílis e Bantos. Era com elas que os capitães de Mombaça negociavam o marfim, escravos, âmbar e ouro que adquiriam mediante o envio de pequenas embarcações em direção ao Sul, a Zanzibar, Quíloa e ilhas Querimba, até Moçambique, ponto estratégico no negócio de escravos para América (BOXER e AZEVEDO, 1960, p. 48-49). Independentemente da discussão sobre a rentabilidade destas transações para a população instalada neste porto costeiro, ele centralizava o comercio dos principais produtos locais e dos reinos vizinhos. Já no séc. XVII, os sucessivos enfrentamentos com os omanitas terão afectado drasticamente a fluidez das ligações. O inimigo arábico constituiu um perigo eminente para o sucesso desta atividade, obrigando à sua proteção armada, já que estas relações mercantis eram estratégicas para a economia do Estado da Índia e dos seus parceiros no Reino (PISSURLENCAR, 1956, p. 468-9). A queda de Mombaça significou assim um duro golpe para a Coroa, comprometendo inclusive o sucesso da Companhia Geral de Comercio das Índias Orientais e o controlo sobre estes circuitos que vinham sendo disputados pelas elites indianas (ANTUNES, 1995, p. 19-29).

Embora as circunstâncias em que este navio chegou a Mombaça não fossem em primeira instancia comerciais, existem claros indícios de que viriam a bordo mercadorias que não se destinavam precisamente ao consumo próprio ou uso pessoal. Se acreditarmos nas palavras de Alexandre de Sousa de Castelo Branco, rapidamente nos damos conta dos interesses económicos acalentados, de modo encoberto pelo capitão. Luís de Mello de Sampaio tinha como missão prestar auxílio ao Forte e daí viajar até Moçambique onde foi destinado como governador. Este seria o motivo pelo qual, durante os preparativos da viagem, se deteve fundamentalmente em negociações com comerciantes, sendo inclusive 
acusado de roubar dinheiro à Misericórdia para tal efeito e descuidar o recrutamento de soldados (B.N.P., Fundo Geral, Códice 584, f.18-20 e 53). Embora estas denúncias possam ser exageradas, elas são o reflexo da enorme corrupção que permitia oportunidades de negócio à revelia da lei. Tal conjuntura deverá ser tida em conta em qualquer análise sobre a circulação de produtos durante a Época Moderna.

De um modo geral, os estudos sobre contas têm progredido, embora exista uma tendência para os enfoques regionais e tipológicos, relegando a realidade portuguesa e ibero-americana, que aqui procuramos explorar. Partiremos da conjuntura peninsular, bem como dos circuitos comerciais em que estava envolvida, para considerar o universo de difusão das contas mais além do seu uso por escravos ou outros grupos marginais. Ainda assim prestaremos especial atenção àqueles aspectos culturais que poderão estar na base da sua difusão.

\section{1- CONTAS DE MATERIAIS NATURAIS}

As contas realizadas em materiais orgânicos e líticos formam o grupo mais numeroso desta amostra, com 15 exemplares: 1 de pedra, 2 de concha, 2 de azeviche, 1 de madeira, e 9 de sementes. Consideradas à partida matérias-primas mais baratas e acessíveis, estes elementos foram recorrente na moda do séc. XVII dando passo inclusive a falsificações mais baratas.

\section{1- CONTAS LITICAS}

A única conta de pedra encontrada foi um exemplar de calcedónia, com mistura de cornalina e ágata. Durante toda e Idade Moderna este tipo designou-se de Laqueca, distinguindo-se pela sua cor branca-opalina, alaranjada e lustrosa. O termo, originalmente atribuído ao material, estendeu-se como sinónimo da contaria que com ele se realizava, embora fosse igualmente empregue no adorno de "brincos, e outras obras como anéis, guarnições de facas, e alfanges" (SOUSA, 1789, p. 112.).

Hist. R., Goiânia, v. 18, n. 2, p. 187-216, jul. / dez. 2013 
$\mathrm{O}$ abastecimento destes produtos fazia-se em diversos pontos do continente asiático, fundamentalmente na Índia e Madagáscar, integrando as redes de comercio inter-regional assaz lucrativas (FLORES, 1991, p. 55-57.). De facto, a Índia foi provedora de uma enorme variedade de gemas aplicadas na joalharia europeia e em outro tipo de suportes.

Os exemplares de laqueca comprados pelos portugueses eram originários do Guzarate, mais concretamente de Limodara (ORTA, 1987, p. 230; VITERBO, 1865, p. 57). Segundo as descrições de Duarte Barbosa, de 1505, os seus artesãos expunham-na ao fogo para torna-la mais vermelha antes de lhe darem forma (BARBOSA, 1995, p. 279). A esta cidade acorriam comerciantes de muitas origens, sobretudo de Cambaia e é possível que estas peças ingressassem nas redes de negocio a partir de Cochim, que centralizava o comercio da pedraria indiana. A prosperidade desta cidade deveu-se sobretudo aos mercadores cristãos-novos de Goa que, graças às suas redes familiares, lograram dominar o mercado regional e a sua exportação para Lisboa (TAVIM, 2003; CUNHA, 2001, p. 289292). A aquisição destes produtos fazia-se através de banianes e guzerates que aí acudiam, ou de mediadores aí assentados que se deslocavam às principais feiras regionais. De facto, a procura foi tão elevada que favoreceu a criação de associações de mercadores e a penetração de estrangeiros nestas redes. A frequência com que se iludiram os registos dos corretores, ou a facilidade em esconder tais objetos entre as géneros embarcadas legalmente, permitiram avultados lucros. Tanto assim foi que se chegou a enviar pedras para a metrópole, onde eram talhadas e levadas de novo para a Índia, embora existissem oficinas de lapidários em Goa (CUNHA, 1995, p. 513-536.). Elas destinar-se-iam fundamentalmente ao consumo de uma elite e seriam encaradas com a mesma curiosidade com que se olhava para as produções orientais na Europa.

Atendendo ao acima exposto, podemos interpretar a presença deste exemplar no âmbito do comercio de produtos asiáticos demandados tanto pelo mercado europeu como africano. No primeiro caso as contas chegavam pela rota do Cabo ou pelo Cairo, integrando complexas transações que uniam o subcontinente indiano ao Medio Oriente, diferentes cidades africanas e a península ibérica. Apesar do seu valor reduzido elas tiveram aceitação junto das elites portuguesas.

Por outro lado, existiu uma longa tradição de uso de contas de cornalina entre vários grupos africanos e que precedeu os contactos lusos nesta zona (LOBATO, 1995, p. 158; Andreia Martins Torres. As CONTAS A BORdo da Fragata Sto. ANTÓNIO dE TANÁ (1697) 
FRANCIS, 2002; WOOD, 2012). Os artigos asiáticos têm sido interpretados quase sempre como objetos de luxo, destinados essencialmente aos consumidores europeus ou às elites, mas houve uma circulação considerável de bens entre a Ásia e África, sobretudo na Costa Oriental. Nestes circuitos, incluíram-se produções indianas que não se circunscreveram aos algodões, embora os tecidos predominassem nas trocas. Elas correspondiam a uma procura local mais que a uma tentativa de escoar géneros invendíveis, ainda que se tenham obtido grandes margens de lucro, sobretudo com as manufacturas mais baratas como estas contas.

No que concerne aos possíveis usos do exemplar em questão, é difícil assegurar que se tratava de parte da carga do navio. Apesar de ter sido efetivamente uma mercadoria tradicional entre as exportações da Índia ele poderia pertencer a um tripulante. Associada a esta hipótese deve referir-se que, ao longo do tempo e por parte de diferentes grupos culturais, foram atribuídos poderes curativos a este material. Denominada correntemente por "pedra de sangue", talvez devido à sua cor avermelhada, atribuiu-se-lhe a propriedade de estancar hemorragias. Isto tornava aquela conta especialmente atrativa para os homens do mar, onde a precariedade de medicamentos e auxílios médicos, fizeram dos amuletos um recurso frequente.

Entre algumas populações muçulmanas foi comum uma variedade de calcedónia, designada de babagore, com a qual se talharam contas muito redondas, como a que foi encontrada no contexto arqueológico em estudo. Estas eram trazidas pelos "mouros nos braços, em lugar que lhes toquem na carne, dizendo que saom boas para guardarem castidade" (BARBOSA, 1995, p. 279) e, se nos remetemos à diferentes origens da população a bordo do Santo António de Taná, esta hipótese não deve ser descartada.

Este tipo de contas tornou-se bastante popular, alcançando os espaços de presença espanhola na América, mesmo naqueles territórios periféricos dos principais vice-reinos. Porém, e até ao momento, os exemplares recuperados em escavações arqueológicas são algo distintos e teriam origem noutras partes da Índia, mais a Sul. Por esse motivo não podemos fazer uma associação direta entre os mercadores portugueses e o abastecimento deste mineral nos contextos referidos, mas seria conveniente aprofundar nesta temática. Os contactos da monarquia espanhola com a Índia estiveram sempre muito limitados e investigações recentes demonstram uma importante presença portuguesa no abastecimento comercial de Manila. 


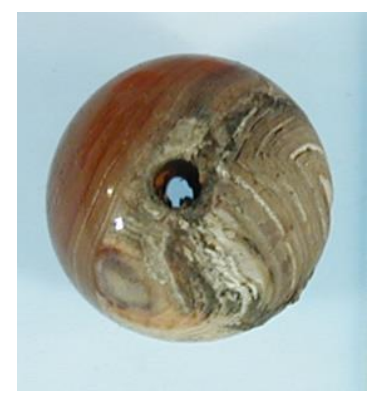

(I- MH 0107 -Diâm. 0.0094 x 0.009; diâm. orifício 0.00125)

\section{2- CONTAS DE CONCHA}

A concha aplicou-se vulgarmente na decoração de móveis e em pequenos objetos de uso doméstico ou de adorno pessoal, como as contas. O tráfico de bivalves e búzios ao longo de toda a costa africana foi um aspecto recorrente durante vários séculos e os portugueses procuram novos centros abastecedores além-mar para fazer face a esta procura nos territórios ocupados. No que concerne aos exemplares da Santo António de Taná, eles estão realizados em madrepérola, mas não nos foi possível proceder a análises no sentido de determinar a sua origem e espécie(s).

Nos mares da Índia, Ceilão e Japão cresce um género de bivalve de grandes dimensões, chegando a alcançar os $20 \mathrm{~cm}$, que poderá ter sido usado para a elaboração de contas. No contexto indiano, este comércio ficou associado fundamentalmente ao de pérolas ou aljôfar, cuja procura foi sempre bastante elevada para aplicação em joalharia. Por outro lado, subsistem registros que nos remetem para transações entre Portugal e as Canárias de um certo tipo de conchas de ostra. Elas foram, a finais do séc. XV, monopólio da coroa no trato com a Etiópia, onde os seus habitantes as usavam ao pescoço como amuleto contra o raio (MÜNZER, 1932, p. 52). Ainda assim elas chegaram a ser adquiridas na costa oriental africana, sobretudo na ilha do Bazaruto, em Moçambique (VASCONCELOS, 1925, p. 67.).

A diversidade de pontos de recolecção da madrepérola e a complexidade das redes

de comercio, aliados ao facto da fragata ter feito escala no Zanzíbar para recrutar reforços na defesa do forte, tornam quase impossível determinar a origem destas peças. 
No que concerne aos usos que puderam ter estas contas, a proximidade de Mombaça com os centros de recolecção de madrepérola leva-nos a descartar que se destinassem ao trato africano. Os exemplares usados pelos nativos seriam facilmente adquiridos junto das populações vizinhas e o espaço a bordo, altamente cotizado, seria preenchido com outras mercadorias mais lucrativas. Por isso, supomos que as peças pertencessem a um individuo a bordo. Este poderia tê-lo adquirido em Goa, porto de origem da fragata, onde existiam numerosos lapidários e joalheiros trabalhando com estas matérias-primas indianas. Em Portugal, a madrepérola foi bastante apreciada, por exemplo, incrustada em rosários de madeira, mas não temos conhecimento de nenhuma joia montada com uma conta semelhante. A sua forma redonda e achatada sugere ainda um botão, esse elemento da moda europeia que acabou por penetrar também na indumentaria asiática, nomeadamente no Japão, onde o vocábulo utilizado para a definir deriva precisamente do português. De qualquer modo a vivencia no mar seria prolífera em intercâmbios culturais e a forma de se vestir ou adornar o corpo a bordo diferia substancialmente do protocolo geral.

Outra possibilidade que cabe considerar é a de que o seu proprietário fosse um desses indivíduos recrutados já em África para a defesa de Mombaça, dado o uso ancestral de conchas e búzios nesta zona e que facilmente se adquiririam no comércio local.

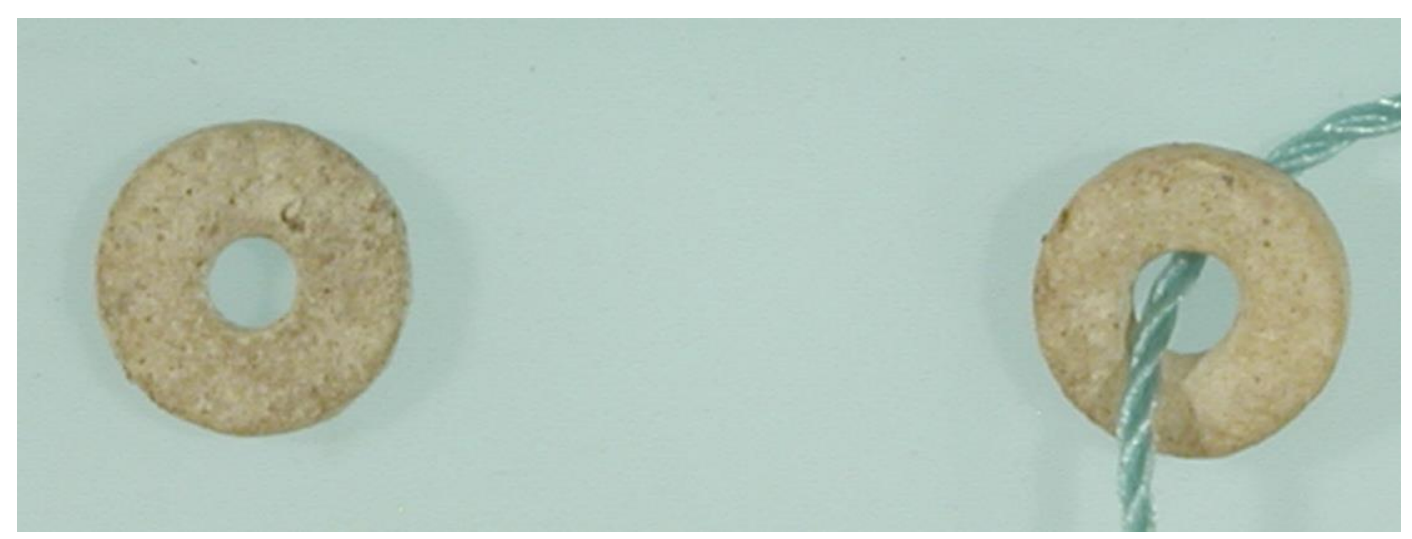

(II- Conta MH 1276-Diâm. 0.0055; diâm. orifício 0.00145 e MH 1565-Diâm. 0.006; h. 0.001; diâm. orifício 0.0014.)

\section{3 - CONTAS DE AZEVICHE}

O azeviche foi usado na Península Ibérica, desde tempos remotos, em joias convencionais de luto e rosários ou em objetos de carácter particular. Dentro do universo da 
religiosidade popular, ele constituiu uma proteção contra o mau-olhado e difundiu-se em amuletos, muitos deles complementados com medalhas de santos ou crucifixos. Com efeito, nesta época as "crenças populares" conviveram de forma muito próxima ao culto oficial da fé católica podendo conjugar-se vários sistemas simbólicos numa única peça, facto assumido pela própria Igreja. As características de tais adornos tornavam-nos especialmente aptos para mulheres e crianças, mas tiveram também sucesso junto da população masculina, embora mais discretamente.

Estes processos híbridos a que nos referimos foram especialmente profícuos no contexto da vida a bordo. A fragata Santo António de Taná constituiu um espaço de convivência de indivíduos de origem e crenças muito diversas, onde certamente proliferaram novos medos, mas também renovadas formas de proteção. Ante o olhar alheio elas surgiriam como algo original e também por isso potencialmente mais efetivas. O desconhecido produziu quase sempre um carácter mágico e por isso a maioria das crónicas de viajantes relatam como os rituais forâneos foram encarados como algo perigoso. Pelos motivos assinalados não podemos fazer uma associação direta entre objecto de determinada cultura e individuo cultural.

Além do significado sagrado, o azeviche foi empregue como símbolo de prestígio, constituindo uma matéria-prima mais cara que o vidro, o osso, ou as sementes, com as quais se elaboravam o mesmo tipo de adornos a um preço mais acessível.

A qualidade e origem do azeviche é diversa, existindo minas por quase todo o mundo, pelo que sem análises de laboratório não é possível determinar a proveniência do material usado na execução destas peças. Na Europa a exploração deste recurso desenvolveu-se, sobretudo na Inglaterra, Espanha, França, Alemanha e Polónia, podendo eventualmente proceder de um destes centros exportadores. Embora terminado o período de união ibérica e tendo Portugal alcançado de novo a sua independência face ao império espanhol, a proximidade com este reino poderá ter favorecido a entrada das suas produções no mercado interno. Esta "indústria" desenvolveu-se especialmente no Norte, relacionandose com as peregrinações a Santiago de Compostela. Assim, sabendo-se que uma das escalas da Santo António de Taná foi a cidade de Vigo, próxima daquele santuário, coloca-se a hipótese, entre muitas outras, destas peças terem sido aqui adquiridas.

$\mathrm{Na}$ Índia existiu uma importante produção de joias em azeviche, nomeadamente em Andreia Martins Torres. As CONTAS A Bordo da Fragata Sto. ANTÓNIO de TANÁ (1697) 
Goa, mas elas vendiam-se também noutras cidades. Sobre os centros abastecedores deste material, supostamente usado nas oficinas goesas ou vendidos noutras cidades indianas, e sobre as redes de comercio das suas produções desconhecemos qualquer trabalho a respeito.

Os dois únicos exemplares de contas deste material recolhidos na fragata correspondem a um tipo de peça cujo uso se difundiu bastante no adorno de elementos de indumentaria, bordados diretamente sobre o tecido ou inclusive como botões. Podem também ter pertencido a um colar ou pulseira, como separador, permitindo articular duas fiadas de contas e realizar composições mais elaboradas. A base lisa possibilitaria um maior apoio sobre o suporte, assim como os laterais, também planos, facilitavam a união de uma conta com outra.

As peças em questão poderão ter pertencido a um dos indivíduos embarcados, ou destinar-se ao comércio que se realizava na costa oriental africana desde o século XVI. Neste caso, a morfologia das peças leva-nos a crer que as mesmas se reservavam às elites instaladas em Mombaça ou Moçambique, mais do que ao mercado nativo. Apesar da população portuguesa nestes assentamentos ser relativamente reduzida, como defendem alguns autores, elas continuariam a demandar os tradicionais símbolos de ostentação da sua categoria social, entre os quais se incluíam estas contas.

Hist. R., Goiânia, v. 18, n. 2, p. 187-216, jul. / dez. 2013 


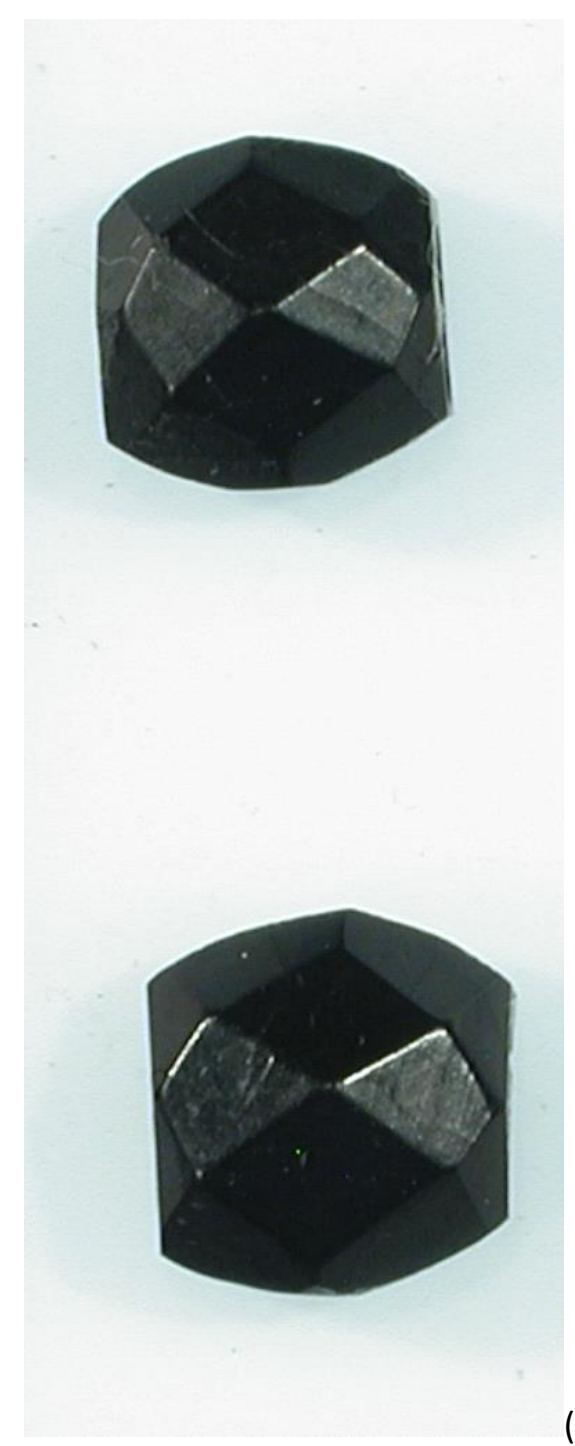

(III- Contas MH 6154-Diâm. 0.0085 x 0.009; diâm. orifício 0.0015 e MH 6406-Diâm. 0.0090 x 0.0095; diâm. orifício 0.0015).

\section{4- CONTAS DE MADEIRA}

O único exemplar recolhido durante as campanhas arqueológicas apresenta uma forma esférica e dimensão relativamente pequena. $\mathrm{O}$ estado em que se encontra o material não permite identificar o tipo de madeira em que está realizada e, portanto, tecer considerações sobre a sua origem.

As aplicações que estes objetos conheceram em Portugal foram muito diversas, destacando-se o seu uso em rosários. Com exceção dos exemplares realizados com Andreia Martins Torres. As contas a bordo da Fragata Sto. ANTÓNIO de TANÁ (1697) 
madeiras raras, estas contas constituíram uma opção barata, sendo usadas por missionários das ordens mendicantes e pela população cristã com menos recursos. No entanto, outras religiões utilizam peças semelhantes para levar a conta das suas orações, nomeadamente entre os grupos étnicos africanos ou indianos que viriam bordo.

A interpretação deste artefacto como objecto comercial é pouco provável dada a existência no mercado local de boas madeiras, como o ébano, com que se poderiam executar contas deste tipo. Tal apenas se justificaria se se tratasse de uma espécie rara no contexto africano. Na realidade, na península foi comum a utilização de madeiras africanas, como o pau-preto, constando entre as joias de alguns inventários de bens de pessoas influentes. As contas de calambuco ou pau de águia ficaram conhecidas pela sua qualidade e cheiro agradável. Elas chegavam a Portugal por via de Goa e foram tão apreciadas que estiveram associadas a joias em metais preciosos finamente lavrados, como por exemplo, filigrana, além de pérolas, diamantes e enfeites de esmalte (RAU, 1947, p. 33-35; PINTO, 2008, p. 241). Outra qualidade registada na documentação para o talhe de contas é o cachundé que também serviu de complemento em pulseiras de diamantes ou pérolas. A algumas destas madeiras foram atribuídos ainda podres mágicos que converteriam a joia num objecto peculiar. Eles são uma evidência mais do comercio de curiosidades e dos intercâmbios culturais que se processaram através da circulação de objetos alheios a um ambiente sociocultural. A novidade do seu aspecto ou da qualidade do material poderiam tornar o que não passava de uma simples conta de madeira para alguns, num objecto especial. Tais circunstâncias poderão explicar a presença deste exemplar na fragata do Santo António de Taná mas nunca saberemos o verdadeiro valor das mesmas para o seu possuidor.

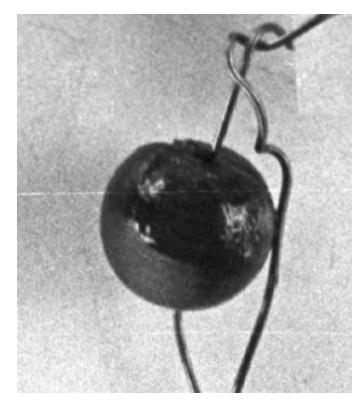

(IV- Conta MH 5998- Diâm. 0.0075) 


\section{5- CONTAS DE SEMENTES}

As sementes foram empregues como opção mais económica para a realização de vários artefactos. Nos territórios americanos do império espanhol conhecem-se algumas fontes que se referem a rosários de "frutilla", compostos precisamente por estas sementes frutais. O seu uso estava bastante disseminado, inclusive entre as classes mais altas, embora o valor das mesmas fosse substancialmente mais baixo que o das congéneres em pedras semipreciosas ou vidro. Em todo o caso, pelo menos nas fontes que observamos, parecem referir-se a produções locais e não a um comercio de curiosidades provenientes de uma região distante. Nos territórios portugueses a realidade seria idêntica, pelo que os achados deverão ter pertencido à tripulação. Além disso, desconhecemos qualquer alusão ao comercio de joalharia com contas de sementes "exóticas" que pudessem constituir um atrativo comercial ao longo da costa africana, ou mesmo na Índia.

Os mantimentos a bordo e o reaproveitamento de algumas sementes, que se encontravam à disposição de todos aqueles que ingressaram nesta derradeira viagem da fragata, constituíam uma matéria-prima acessível para elaborar artesanalmente adornos corporais. Por este motivo a manufactura de alguns dos exemplares em estudo poderá ter sido o resultado de um ato fortuito que não obedeceu tanto a um critério estético ou simbólico como de reaproveitamento. Isso explicaria também o facto de ser um dos grupos mais representativo desta coleção, com nove exemplares.

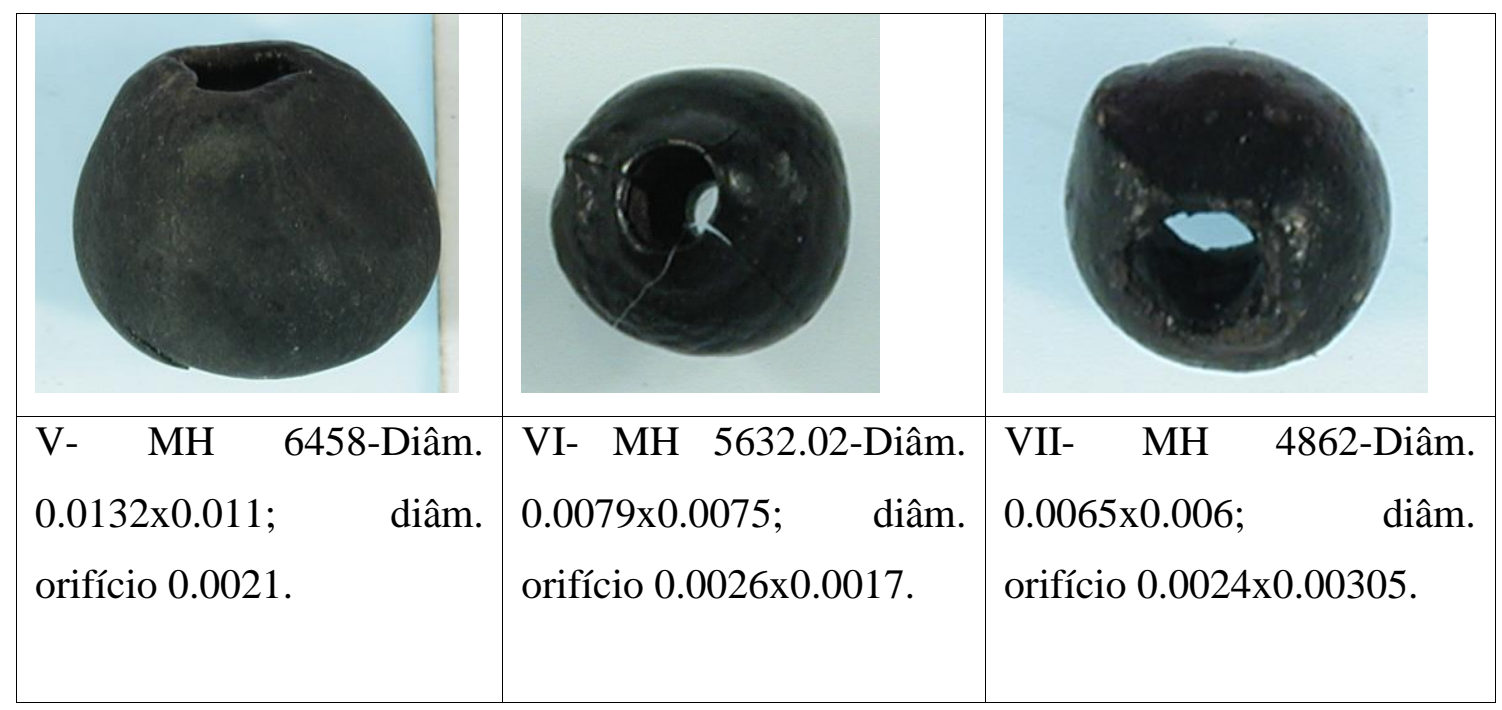




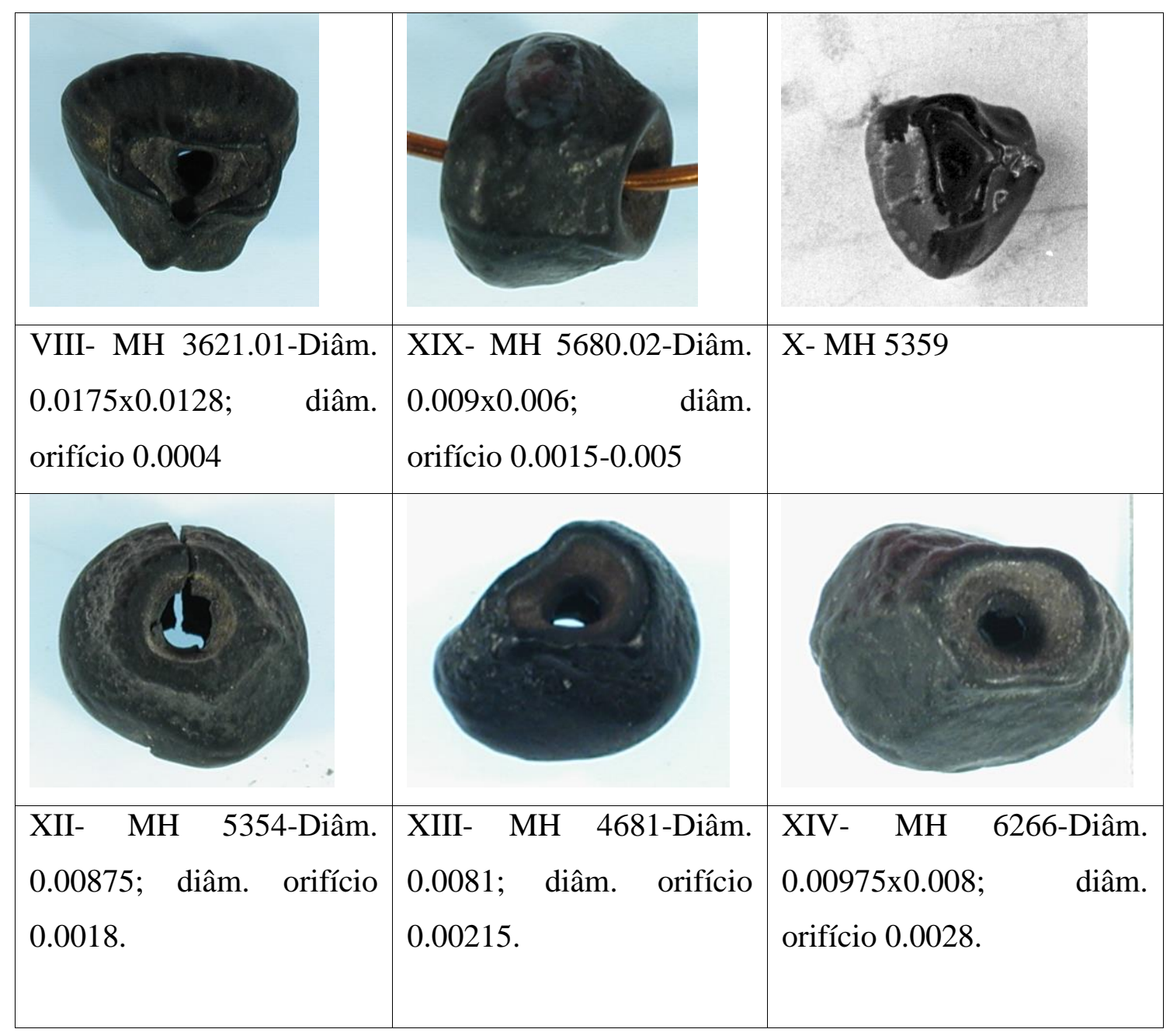

\section{2- CONTAS DE VIDRO}

Entre os artefactos encontrados no decurso da intervenção arqueológica destaca-se uma interessante coleção de 24 contas de vidro. Durante os séc. XVII e XVIII elas foram designadas de diferentes formas, consoante as suas características. Em todas as definições de época se associam estes géneros ao comércio africano, mencionando que os mesmos se destinavam ao adorno dos cafres na Costa da Mina, ou para o trato americano. África aparece como o principal centro de operações relacionadas com este negócio mas haveria que pontualizar sobre a sua importância no Novo Mundo e de que modo estes dois espaços geográficos se associaram através das contas de vidro. No Brasil as escavações de contextos funerários têm permitido constatar a grande difusão dos avelórios durante toda a 
época de presença portuguesa, sobretudo entre a população negra (MEGGERS, BETTY e EVANS,1957;GUAPINDAIA,2001, p. 156-174; TAVARES, 2006; OZANAN, 2003, p. 61-77). Em alguns casos, foram detectados os mesmos modelos, indicando uma ligação entre a circulação de indivíduos e alguns aspectos da sua cultura material, muito embora eles não sejam necessariamente de produção local, mas sim importações. Ainda assim, houve um comercio regular de contas de vidro em todo o continente americano e não se poderá limitar a sua interpretação ao contexto estrito do tráfico de escravos. Tanto nas capitanias portuguesas como nos vice-reinados espanhóis, estes objetos constituíram um elemento sempre presente entre as populações indígenas ou mesmo crioulas. Eles favoreceram o desenvolvimento de expressões artísticas autóctones (Carvalho, 2008) que estiveram condicionadas também pela maior ou menor articulação de cada cidade com os grandes circuitos de abastecimento destes produtos. Em ambos os casos, o impacto local das contas proporcionou a manutenção dos sistemas de diferenciação social, atuando ora como elemento de prestígio ora aplicando-se de acordo a estéticas próprias de cada ator social (TORRES, no prelo).

Atendendo ao acima exposto haveria que refletir sobre o significado da amostra em estudo, ou seja, de que modo a situação geopolítica e económica do império português favoreceu a sua presença a bordo da fragata. Para isso é fundamental identificar os centros produtores e perceber as redes que permitiram a sua circulação no contexto do Oceano Índico e mais além dele. A grande dispersão de determinados modelos exige que se considerem igualmente os seus eixos de articulação com as principais rotas comerciais desse período e é o que trataremos de expressar a continuação.

A maioria das contas do trato africano entraria nas redes comerciais através de Lisboa. Elas integravam a "Fazenda Real" gerida pela Casa da Mina, um dos grandes símbolos do poder português à época, e que termina por se vincular também a este negocio. Ele seria de tal modo rentável que o Estanque do Velório só foi abolido em 1761, demonstrando a grande resistência da coroa em abdicar deste exclusivo numa altura em que a tendência foi a de liberar o mercado à iniciativa privada.

Uma grande parte das contas eram embarcadas no porto da capital e transportadas em barricas, ensartadas em fios (mites) ou em milheiros conformando conjuntos que, em alguns casos, adquiriram designações próprias. A uniformidade das medidas permitiu que Andreia Martins Torres. As contas a Bordo da Fragata Sto. ANTÓNIO de TANÁ (1697) UM EXEMPLO DE INTERCÂMBIOS NUM MUNDO GLOBAL 
servissem como moeda na costa africana, pelo menos até inícios do séc. XIX.

Como deixam antever as referências, o avelório foi um dos principais produtos do trato africano mas, tanto em Espanha como em Portugal, os fornos de vidro só esporadicamente produziram contas. Até ao momento desconhecemos qualquer evidencia de manufacturas destinadas à exportação, nem mesmo para os períodos iniciais de ocupação do continente americano, como se tem defendido (Deagan, 1987, p. 158-159; Smith e Good, 1982, p.12-15). De onde vinha então a grande quantidade de contas que saíam da capital com destino às feitorias africanas ou inclusive consumidas no país?

A produção das contas de vidro na Europa esteve, durante muito tempo, dominada pelas cidades italianas de Veneza e Murano. Este monopólio assentava sobre um forte controle da mão de obra qualificada. Os conhecimentos transmitiam-se dentro de uma mesma família, e as autoridades locais impunham duras penas àqueles que ousassem divulga-los a terceiros ou implementassem a sua atividade noutras zonas. Apesar de tudo, a partir do séc. XVII a tecnologia propaga-se um pouco por toda a Europa central. Este foi o caso, por exemplo, de Inglaterra, Alemanha, Holanda ou do então denominado Reino da Bohemia que se destacou pelas suas peças de vidro translúcido. Tais iniciativas ocorreram no âmbito de estratégias económicas concertadas que basearam o incremento das manufacturas nacionais na capacidade de atrair especialistas. No caso do vidro, as inovações vão surgindo a um ritmo relativamente lento, resultando de adaptações às circunstâncias dos mercados locais, bem como às matérias-primas disponíveis. O objetivo foi sempre o de imitar o produto de grande qualidade característico das oficinas venezianos e de Altare tornando-se, a finais da centúria, em fortes concorrentes no mercado de exportação. Como consequência, a identificação dos centros produtores destes exemplares torna-se algo complicada sem análises de laboratório.

As fontes portuguesas atestam a importação de contas da Itália e de Hamburgo com destino a África. De facto foram recuperados dois tipos de contas na Santo António de Taná que obedecem a uma técnica originalmente veneziana, e que se difundiu também pelos Países Baixos, denominada rocailles of compound construction. O primeiro grupo compõese de oito exemplares de contas anelares, formadas por duas camadas sobrepostas de cor branca de tom ligeiramente distinto, sendo a externa mais escura e brilhante; o orifício central varia entre o circular ou oval. Elas foram concebidas a partir de uma barra de vidro 
seccionada e, por isso, em alguns casos, o corte é diagonal e a espessura muito variável. Até ao momento não pudemos identificar este tipo de conta em Portugal, mas ele aparece em vários sítios arqueológicos em África, nomeadamente em "Mapungubwe Hill" ou em Kondo, na Etiópia. No primeiro caso elas foram classificados como produções europeias do séc. XVII-XVIII (TOURNIÉ, PRINSLOO e COLOMBAN, 2012, p.532-542), no segundo, refere-se apenas a sua semelhança com as dos estratos mais antigos (KIMURA e SHENKERE, 2009, p. 369-381). Na realidade, esta limitação está patente em vários estudos africanos onde se localizou este modelo. Na maioria dos casos, eles centram a sua análise na composição do vidro para identificar os centros produtores, com barreiras cronológica muito alargadas. A sua difusão no tempo abarca vários séculos e abrange zonas geograficamente muito distintas o que nos coloca problemas de interpretação. Elas chegam por exemplo ao continente americano, nomeadamente na Georgia, aparecendo em naufrágios de navios negreiros como o Queen Anne's Revenge, localizado na Carolina do Norte (FLOWER, MCNAUGHTON e MYERS, 2007, p. 1-10). Sem embargo, isso não significa que elas penetrassem pelas mesmas vias. Os holandeses exportaram as suas produções para a Europa, mas tal como os portugueses, eles utilizaram as contas de vidro nas suas trocas diretas com a Ásia e a América, em circunstâncias que variam muito em função da conjuntura política de cada momento. Os avelórios são quiçá o objeto que melhor permite compreender o sistema de comercio mundial que caracterizou os tempos modernos. Como a disputa por determinados mercados se realizou fundamentalmente mediante a constante adaptação às exigências locais e como elas favoreceram o desenvolvimento de certas manufacturas ou a manutenção de dependências face ao estrangeiro. Por isso mesmo é extremamente complicado seguir o rasto de todos os intermediários comerciais envolvidos na distribuição deste produto.

O segundo grupo está constituído por três exemplares designados "green heart beads", "indian red over green " ou "indian rouge". Caracterizam-se pela cor vermelha opaca e cerne verde, normalmente translúcido, embora existam variantes com núcleo branco ou amarelo (OPPER e OPPER, 1989, p. 5-20; BLAIR, PENDLETON e FRANCIS JR., 2009, p. 59-64). Nos três casos identificados o interior é verde opaco que dever-se-á a uma degradação do vidro mais que do que ao tom original. Dois desses exemplares mostram ainda incisões longitudinais realizadas posteriormente à sua confecção, numa Andreia Martins Torres. As CONTAS A BORdo da Fragata Sto. ANTÓNIO dE TANÁ (1697) 
provável adaptação à estética local. Este tipo espalhou-se pela costa ocidental africana no século XVII, encontrando paralelos nos tipos 75 e 76 de Juffure e no tipo 14 de Elmina (GIJANTO, 2011, p. 637-668; DECORSE, RICHARD e THIAW, 2003, p. 77-110). A terceira peça é ligeiramente distinta, já que a capa vermelha exterior envolve o núcleo verde. Esta variante foi identificada em África do Sul, em Mugombane e em Kaditshwene (ESTERHUYSEN, 2006, p. 33). A sua concentração nesta zona poderá ser um indício da existência de uma rede de distribuição por via atlântica e diretamente a partir da Europa já que, até ao momento, a sua presença no Índico é mais residual. No entanto, este modelo foi encontrado igualmente nas Filipinas, em Calatagan (DAVISON, 1972, p. 209), e em contextos de ocupação espanhola na América do Norte, na Florida, no Texas, na Louisiana (BENSON, 1967, p. 118-132; HARRIS, 1965, pp. 307-315; JELKS, 1966, p. 97-104; DUFFIELD E JELKS, 1961, p. 40-54; GREGORY e WEBB, 1965, p. 15-44; QUIMBY, 1966, p.81-90), sendo classificadas como manufacturas italianas ou holandesas, neste último caso produzidas desde antes de 1610 (BLAIR, PENDLETON e FRANCIS JR., 2009, p. 63, 89 e 161; KARKLINS, 1985, p. 36-4; BAART, 1988, p. 70 e 73).

Além destes tipos compostos ou compósitos, existem vários modelos mais simples, as designadas "rocaille of simple construction". Elas têm formato anelar ou tubular e a variedade cromática desta coleção é reduzida, onde predomina o azul. Tal facto poderá indicar um destino comercial para estes objetos, tentando ir ao encontro do gosto local. A simplicidade das formas e a pouca diafanidade do vidro não requeriam habilidades especiais na sua produção, pelo que é difícil atribui-las a uma tradição vidreira concreta.

Ainda assim, entre o espólio da Santo António de Taná contam-se cinco contas de vidro quase negro opaco, semelhantes às que foram usadas antes da penetração europeia em África, as trade wind beads, posteriormente imitadas pelas manufacturas europeias. Este modelo encontra-se também na Península Ibérica, tendo sido recuperado um exemplar num enterramento da Igreja Santiago Apóstol, em Villa del Prado (Madrid). Além disso, foram exumadas na fragata quatro contas em azul de cobalto opaco e duas em azul marinho opaco, muito parecidas às que têm surgido em diferentes escavações no Senegal e é provável que o centro produtor fosse o mesmo. Em azul mais claro e opaco recolheu-se uma conta, com paralelos na África do Sul. A única peça vermelha-violeta tem forma cilíndrica e a identificação do seu centro produtor é igualmente difícil de determinar. Este 
tom é característico das produções italianas ou da Bohemia e assemelha-se ainda a algumas produções indianas, mas de cronologias mais recuadas. Por isso apontamos para uma produção europeia e não asiática

Se bem a coleção em estudo está composta por várias contas de produção europeia, existiu uma circulação destes objetos diretamente a partir da Ásia. Ela está representada por uma única conta cujo modelo foi encontrado em contextos arqueológicas na província de Limpopo (África do Sul) ou integrando antigas relíquias de família do séc. XIX (ESTERHUYSEN, 2006). Tratam-se de joias montadas com elementos mais antigos atribuídos às oficinas indianas do séc. XVII e que demonstram a larga previdência destes elementos no tempo e à qual está implícita a grande estima em que sempre se tiveram. Esta fraca representatividade explica-se pela mudança dos parâmetros de comércio no Índico. Por um lado assiste-se a uma relocalização dos centros de produção em função da proximidade com cidades e portos de escoamento e por outro à penetração das produções europeias. $\mathrm{Na}$ costa oriental africana as contas indianas vão perdendo mercado em detrimento das europeias, mas a sua difusão continua a ser mais preponderante aí que na zona Atlântica onde chegaram a ser vendidas na Gâmbia.

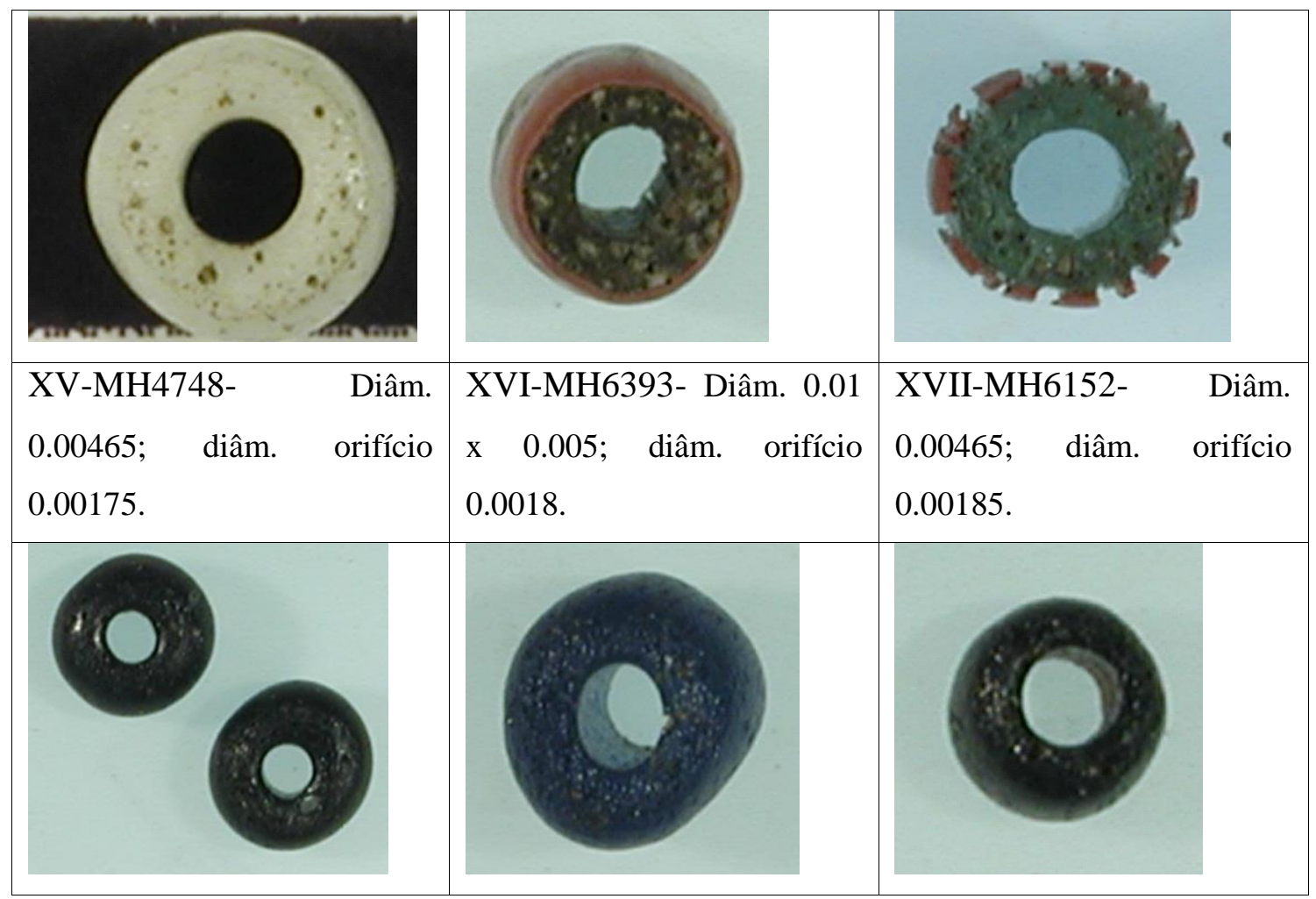

Andreia Martins Torres. As CONTAS A BORdo DA FraGATA Sto. ANTÓNIO DE TANÁ (1697) UM EXEMPLO DE INTERCÂMBIOS NUM MUNDO GLOBAL 


\begin{tabular}{|c|c|c|c|}
\hline $\begin{array}{l}\text { XVIII-MH5214- Diâm. } \\
0.00365 \text { e } 0.00314 \text {; diâm. } \\
\text { orifício. } 0.001 \text { e } 0.0011 \text {. }\end{array}$ & $\begin{array}{l}\text { XIX-MH5792- } \\
0.005 ; \quad \text { diâm. } \\
0.00135 .\end{array}$ & $\begin{array}{l}\text { Diâm. } \\
\text { orifício }\end{array}$ & $\begin{array}{l}\text { XX-MH } 5603-\quad \text { Diâm. } \\
\text { 0.003; diâm. orifício } 0.001 .\end{array}$ \\
\hline $\begin{array}{l}\text { XI-MH6264- Diâm. 0.0044; } \\
\text { diâm. orifício } 0.00225 \text {. }\end{array}$ & $\begin{array}{l}\text { XXI-MH5227- } \\
0.0033 ; \quad \text { diâm. } \\
0.0015 .\end{array}$ & $\begin{array}{l}\text { Diâm. } \\
\text { orifício }\end{array}$ & $\begin{array}{llr}\text { XXIII-MH5680- } & \text { Diâm. } \\
0.004 ; \quad \text { diâm. } & \text { orifício } \\
0.00175 . & & \end{array}$ \\
\hline
\end{tabular}

\section{CONSIDERAÇÕES FINAIS}

O estudo da coleção de contas que vinham a bordo do Santo António de Taná permitiu ter uma perspectiva da articulação das redes comerciais que uniam a Europa à Ásia e África, tendo como tela de fundo Mombaça. O navio foi construído muito possivelmente nos estaleiros de Taná, próximo a Goa e realizou várias viagens à Europa, passando inclusive pelo Brasil. Este percurso é bastante sintomático da articulação dos vários espaços do Império Português e reflete-se claramente na amostra de contas, sejam elas de materiais orgânicos ou em vidro. Como pudemos observar, elas são o produto de manufacturas de diferentes continentes que testemunham a circulação de pessoas e bens de uso pessoal ou para o comercio. Nestas embarcações não viajavam unicamente mercadorias mas sobretudo indivíduos muito diferentes com interesses e percepções também diversas. São a estas personagens que nos remetem estes exemplos da cultura material. Eles permitem-nos conhecer os interesses e motivações que estiveram por detrás da sua aquisição ou, pelo menos, conjecturar acerca dos mesmos. Isso só é possível se entendermos precisamente como se concebiam estes corpos, a defesa da sua integridade física ante os perigos do mar, a sua definição ante os outros e também a sua percepção, já que a bordo imperaria a diversidade étnica. É também mediante o entendimento das suas ambições socio-económicas que podemos perceber estas pessoas. Referimo-nos à sua maior 
ou menor capacidade de estabelecer contactos comerciais, comprar mercadorias e eventualmente aceder ao crédito para poder dedicar-se a um comercio cuja rentabilidade era praticamente garantida. Estes homens, e pontualmente talvez também mulheres, encararam as contas de forma muito desigual. Enquanto uns viam nelas uma matéria-prima para o adorno corporal ou inclusive para a sua proteção (fosse um amuleto ou um rosário), para outros elas não eram mais que um negócio que exigia certo controle ou proximidade com o sistema burocrático e o aparato político, além de bons contactos com intermediários estrangeiros.

Recordemos que as contas eram monopólio Real e que o objectivo desta fragata era a defesa da Fortaleza de Jesus que, entretanto, trazia a bordo aquele que iria ser o governador de Moçambique. Luís de Melo Sampaio estava autorizado a transportar bens de uso pessoal mas desconhecemos que lhe tenha sido concedida alguma autorização especial para se imiscuir em negócios reservados à Coroa.

Se efetivamente estas contas se destinavam ao comercio, haveria que distinguir essencialmente dois grupos. As produções indianas, que se enquadram no âmbito das tradicionais relações entre a África Oriental e a Ásia Ocidental, das europeias. No primeiro caso elas refletem o papel central de Mombaça como centro de distribuição desde tempos ancestrais, significando um retorno quase garantido do investimento, principalmente em ouro ou marfim. Por outro lado a presença de manufacturas europeias expressa uma mudança nos parâmetros estéticos vigentes até então já que elas eram mais comuns ao longo da Costa Atlântica. Elas foram levadas da Europa para a Ásia e embarcadas em Goa com destino a África, sem que isso significasse que viriam diretamente de Lisboa. Seria mais fácil compra-las por exemplo a franceses, holandeses ou ingleses, com quem se chega a comercializar quando os navios portugueses se atrasam, apesar de serem os principais concorrentes económicos do Império Português no Oriente.

\section{Beads Abord the Sto. Antonio de TANa: An interchange EXAMPle in a global WORD}

ABSTRACT: This article analyses the beads found during the excavation of the frigate Sto. António de Tána, sank in Mombasa in the year 1697, these allow questioning links between 
India and Africa. We focus primarily on trade issues, but also on concepts and ideas transmitted through the material culture.

KEYWORDS: Glass beads; Modern Archaeology; Africa.

\section{BIBLIOGRAFIA}

ARRUDA, A. M.; C. Viegas e M. J. Almeida (coord.). De Scalabis a Santarém. Catálogo da exposição. Lisboa: Instituto Português de Museus, 2002.

ADAM, Jones (transcribed, translated, and edited). West Africa in the Mid-Seventeenth Century: An Anonymous Dutch Manuscript. African Historical Sources. Atlanta, n. ${ }^{\circ}$ 10, 1995.

ANDRADE, Antonio Alberto Banha de. História de um fidalgo quinhentista Português, Tristão da Cunha. Lisboa: Faculdade de Letras da Universidade de Lisboa, Instituto Histórico Infante Dom Henrique, 1974.

ANTUNES, Luís Frederico. A crise no Estado da Índia do final do século XVII e a criação das Companhias de Comércio das Índias Orientais e dos Baneanes de Diu. Mare Liberum, Lisboa, n. 9, p. 19-29, 1995.

BAART, J. Glass bead sites in Amsterdam. Historical Archaeology. s.1, vol. 22, nº1, p.67$75,1988$.

BARBOSA, Duarte. A description of the coasts of East Africa and Malabar in the beginning of the sixteenth century, (tr. Henry E. J. Stanley), New Delhi: Asian Educational Services, 1995.

BENSON, Carl A. The Philip Mound: A Historic Site. The Florida Anthropologist. Florida, vol. 20, n. 3-4, p. 118-132, Sep.-Dec. 1967.

BLAIR, E.; PENDLETON, Lorann; FRANCIS JR, Peter. The Beads of St. Catherines Island. Anthropological papers of the American Museum of Natural History, n. 89, New York, 2009.

BLOT, J-Y; BLOT M. L. Report on a Research in India and Portugal on the Historical 
Aspects of the 17th Century Portuguese Frigate Santo Antonio de Tanna Sunk in Mombasa, Kenya, November, 1697. Texas A\&M: Institute of Nautical Archaeology, 1984.

BLUTEAU, Raphael. Vocabulario Portuguez e Latino, vol. II, Coimbra: no Collegio das Artes da Companhia de Jesus, 1713.

Vocabulario Portuguez e Latino, vol. IX, Lisboa: Officina de Joseph Antonio da Sylva, 1727

BOXER, C; AZEVEDO, Carlos de. A Fortaleza de Jesus e os Portugueses em Mombaça: 1593-1729. Lisboa: Centro de Estudos Históricos Ultramarinos, 1960.

BRÁSIO, António; Monumenta Missionaria Africana, série 2, vol.3. Lisboa: Academia Portuguesa da História, 1964.

BUTTERWORTH, J. S. Chemical analysis of archaeological deposits from Thatwane Hills, Botswana. South African Journal of Science, s.1., n. 75, p. 408-409, Sep. 1979.

CARVALHO, Francismar de. Entre dois impérios: lideranças indígenas e colonizadores espanhóis e portugueses no vale do rio Paraguai (1770-1810). Anais Eletrônicos do VIII Encontro Internacional da ANPHLAC, Vitoria, p.1-27, 2008. Disponível em: www.anphlac.org.

CECHINI, Isabella. Troublesome Business: Dealing in Venice, 1600-1750. In: DE MARCHI, Neil; MIEGROET, Hans J. Van (eds.). Mapping Markets for Paintings in Europe, 1450-1750, Turnhout: Brepols, 2006, p.116-122

CASTANHEDA, Fernão. Historia da descubrimiento e conquista de India pelos Portuguezes, Livro I, $11^{\text {a }}$ ed. Lisboa: Na typographia Rollandiana, 1833.

CUNHA, João Teles. Hunting Riches: Goa's gem trade in the early modern age. In: MALEKANDATHIL, Pius; MOHAMMED, T. Jamal [Eds.]. The Portuguese, Indian Ocean and European Bridgeheads. Festschrift in Honour of Prof. K.S.Mathew, s/1: Fundação Oriente, 2001, pp. 269-304.

Economia de um Império: Economia Política do Estado da Índia em Torno do Mar Arábico e Golfo Pérsico: Elementos Conjunturais: 1595-1635; (Tese mestrado em História dos Descobrimentos e da Expansão Portuguesa, séc. XV-XVIII, Univ. Nova de Lisboa), Andreia Martins Torres. As contas a Bordo da Fragata Sto. António de TANÁ (1697) 
Lisboa, 1995.

DALGADO, Sebastião Rodolfo. Glossário Luso-Asiático, vol. 1, Hamburg: Buske, 1982.

DAVISON, Claire. Glass beads in african archeology: results of neutron activation analysis, suplemented by results of $x$-ray fluorescence analysys, California: Lawrence Berkeley Laboratory, University of California, Sep. 1972

DEAGAN, Kathleen; Artifacts of the Spanish Colonies of Florida and the Caribbean, 1500-1800. Washington D.C.: Smithsonian Institution, 1987.

DE CORSE, Christopher; RICHARD, François; THIAW, Ibrahima. Toward a sistematic bead description system: a view from the Lower Falemme, Senegal. Journal of African Archeology, s.1., vol 1, n.1, p. 77-109, 2003.

DUFFIELD, Lathel F.; JELKS Edward B. The Pearson Site. Archaeology Series, Austin, n. 4, p.40-54, 1961

DUSSUBIEUX, L.; et al. The trading of ancient glass beads: new analytical data from South Asian and East African soda-alumina glass beads. Archaeometry, Oxford, vol. 50, n. 5, p. 797-821, Oct. 2008.

ESTERHUYSEN, Amanda Beth. Let the Ancestors Speak: an archaeological excavation and re-evaluation of events prior and pertaining to the 1854 siege of Mugombane, Limpopo Province, South Africa, (tese de doutoramento). Johannesburg: Faculty of Science, University of the Witwatersrand, 2006.

FELNER, Rodrigo José de Lima. Subsidios para a História de Índia Portugueza. Lisboa: Academia Real das Sciencias, 1868.

FERNANDEZ de Navarrete, Martin. Colección de los viages [sic] y descubrimientos que hicieron por mar los españoles desde fines del siglo $X V$ : con varios documentos inéditos concernientes a la historia de la Marina Castellana y de los establecimientos españoles en Indias. Viajes de Colón, Almirantazgo de Castilla, vol. 1. Madrid: en la Imprenta Real, 1825.

FLORES, Jorge. Os portugueses e o Mar do Ceilão, Lisboa, (dissertação de Mestrado em História dos Descobrimentos e da expansão Portuguesa na fcsh-UNL), Lisboa: FCSH, 
1991.

FLOWER, Linda; MCNAUGHTON, Carnes; MYERS, Susan. Beads Recovered from Shipwreck 31CR314 Queen Anne's Revenge Site. Queen Anne's Revenge Shipwreck Project. Research Report and Bulletin Series. USA, vol. 7, n. 2 , p. 1-10, 2007.

FRAGA, Tiago Miguel. Santo António de Tanná: story, excavation, and reconstruction. In: CASTRO, L. F.; CUSTER, K. (ed.). The Edge of Empire. Proceedings of the Symposium held at SHA 2006, Sacramento, California. Lisboa: Caleidoscópio, 2008.

FRANCIS, Peter. Asia's Maritime Bead Trade 300B.C to the present. Hawai: University of Hawaii Press, 2002.

GASPARETTO, A. Il vetreo di Murano: dalle origini ad oggi. Veneza: Neri Pozza, 1958.

GIJANTO, Liza. Personal Adornment and Expressions of Status: Beads and the Gambia River's Atlantic Trade. International Journal of Historical Archaeology, s.1., vol. 15, p. 637-668, Dec. 2011.

GREGORY, Hiram A.; WEBB, Clarence. European Trade Beads from Six Sites in Natchitoches Parish, Louisiana. The Florida Anthropologist. Florida, vol. XVIII, n. 3, Part 2, p. 15-44, Sep. 1965.

GUAPINDAIA, Vera L.C. Encountering the Ancestors: the Maracá furnerary urns. IN: MCEWAN, C.; BARRETO, C.; NEVES, E. (ed.) Unknown Amazon, Nature in Culture in Ancient Brazil. London: British Museum Press, 2001, p. 156-174.

HARRIS, R. K. et al. A Preliminary Archeological and Documentary Study of he Womack Site, Lamar County, Texas. Bulletin of the Texas Archeological Society, Texas, vol. 36, p. 307-315, 1965

JELKS, Edward. The Gilbert Site - A Norteno Focus Site in Northeastern Texas. Bulletin of the Texas Archeological Society. Texas, vol. 37, p. 97-104, 1967.

KARKLINS, K. Early Amsterdam trade beads. Ornament, s.1, vol. 9, n. 2, p. 36-41, 1985

KIMURA, Birgitta; SHENKERE, Dinote Kusia. Beads in Konso, Southern Ethiopia. In: EGE, SVEII et al. (ed.). Proceedings of the 16th International Conference of Ethiopian Studies. Trondheim: Norwegian University of Science and Technology, 2009, p. 369-381. Andreia Martins Torres. As CONTAS A BORDO DA FRAGATA STO. ANTÓNIO DE TANÁ (1697) 
KIRKMAN, J. 1975. Fort Jesus: Mombasa, $8^{\mathrm{a}}$ ed. Mombasa: Museum Trustees of Kenya, 1975.

LAPHMAN, Heather; More than a "a few blew beads": The glass and stone beads from Jamestown Rediscovery's 1944-1997 excavations. The Journal of Jamestown Rediscovery Center. Jamestown, vol. 1, s.p., Jan 2001.

LEÃO, Duarte Nunes de. Descrição do reino de Portugal. Lisboa: Jorge Rodriguez, 1610.

LINSCHOTEN, Jan Huygen van; Itinerário, Viagem ou Navegação para as Índias Orientais ou Portuguesas (Arie Pos and Rui Manuel Loureiro eds.), Lisboa: Comissão Nacional para as Comemorações dos Descobrimentos Portugueses, 1977.

LOBATO, Alexandre. Evolução administrativa e económica de Moçambique, 1752-1763. Lisboa: Alfa, 1989.

A Expansão Portuguesa em Moçambique de 1498 a 1530, vol. VIII. Lisboa: Centro de Estudos Históricos Ultramarinos, 1960.

LOBATO, Manuel. Relações Comerciais entre a Índia e a Costa Africana nos séculos XVI e XVII. O papel do Guzerate no Comercio de Moçambique. Mare Liberum. Portugal, ${ }^{\circ}$ 9, p. 157-173, Julho 1995.

LOVE, Ronald S. Maritime Exploration in the Age of Discovery, 1415-1800. USA: Greenwood Publishing Group, 2006.

MARTINS, Andrea et al. Sobre um conjunto de silos em Beja: a Av. Miguel Fernandes. Revista Portuguesa de Arqueologia. Lisboa, vol. 13, 2010, p.145-165.

MEGGERS, Betty; EVANS, C. Archaeological Investigations at the Mouth of the Amazon. Bureau of American Ethnology. Washington, Boletim 167, 1957.

OPPER, M.; OPPER, H. Diakhite: A study of the beads from an eighteenth and nineteenth century burial site in Senegal, West Africa. Beads: Journal of the Society of Bead Researchers. USA, nº1, p. 5-20, 1989.

ORTA, Garcia da. Coloquios dos simples, e drogas he cousas mediçinais da India, e assi dalguas frutas achadas nella onde se tratam alguas cousas tocantes a medicina, pratica, $e$ outras cousas boas, pera saber. $2^{\text {a }}$ ed. fac-similada. Lisboa: Imprensa Nacional, 1987. 
OZANAN, Luiz. As joias dos negros: usuários e artífices nas Minas Gerais do século XVIII. Revista da FADOM, Divnópolis, n. 13, p. 61-77, $1^{\circ}$ semestre de 2003.

PIERCY, R. 1978. "Mombassa Wreck Excavation. Second Preliminary Report, 1978.” in IJNA, Portsmouth, vol. 7, n. 4, p. 301-319, 1978.

PINTO, Fernão Mendes; Peregrinaçam: Texto Primitivo, Inteiramente Conforme à Primeira Edição de 1614, (tradução de Adolfo Casais Monteiro), vol. II. Lisboa: Sociedade de Intercâmbio Cultural Luso-Brasileiro Lda., 1953.

PINTO, Pedro. Um olhar sobre a decoração e o efémero no Oriente: a relação dos bens embarcados em Goa em 1559 para o Reino, o inventário dos bens do vice-rei D. Martim Afonso de Castro, falecido em Malaca, em 1607, e a relação da entrada do vice-rei D. Jerónimo de Azevedo em Goa, em 1612. Separata Revista de Artes Decorativas. Porto, $\mathrm{n}^{\mathrm{o}} \cdot 2,2008$.

PIRES, Thomaz. Amuletos Alentejanos. Estudos e notas Elvenses. Elvas, vol. V, p. 1-40, 1904.

PISSURLENCAR, Panduronga. Portuguese Records on Rustamji Manockje, the Parsi Broker of Surat. Nova-Goa: printed by the autor, 1933.

Assentos do Conselho de Estado, vol. 4. Goa: Tip. Rangel, 1956.

QUIMBY, George Irving. Indian Culture and European Trade Goods: The Archaeology of the Historic Period in the Western Great Lakes Region. USA: The University of Wisconsin Press, 1966.

RAU, Virginia. Inventário dos bens da Rainha da Grã-Bretanha D. Catarina de Bragança. Coimbra: Biblioteca da Universidade, 1947.

ROBERTSHAW, Peter et al. Southern African glass beads: chemistry, glass sources and patterns of trade. Journal of Archaeological Science. vol. 37, n. 8, p. 1898-1912, Aug. 2010 RODRIGUES Garcias, Justina. Vidrio de los Siglos XV, XVI y XVII. Barcelona: Planeta Agustini.

SANTOS, Marília Nogueira dos. Do Oriente ao Atlântico: a Monarquia Pluricontinental portuguesa e o resgate de Mombaça, 1696-1698. In: GUEDES, Rodrigo (org.) Dinâmica Andreia Martins Torres. As CONTAS a bordo da Fragata Sto. ANTÓNIO de TANÁ (1697) 
Imperial no Antigo Regime Português: escravidão, governos, fronteiras, poderes, legados. Brasil: Mauad X, 2011

S.B.M.F.C.L.D. Diccionario Geográfico Universal por una Sociedad de Literatos, Tomo VII. Barcelona: Imprenta de José Torner, 1832.

Sociedade de Estudos de Moçambique. Boletim da Sociedade de Estudos de Moçambique, nº 120-25. Lourenço Marques: Sociedade de Estudos de Moçambique, 1960.

SILVA, Antonio Morais da. Diccionario de Lingua Portugueza, vol. I-II. Lisboa: Typographia Lacerdina, 1789

SILVA, Nuno Vassalo; A ourivesaria entre Portugal e a India. Do séc. XVI ao séc. XVIII. Lisboa: Santander Totta, 2008, ."E muy rica prata fina, de bestiães bem lavrados" A ourivesaria entre Portugal e a Índia, do séc. XVI ao séc. XVIII (Tese de doutoramento na faculdade de Letras da Univ. de Coimbra) Coimbra: F.L, 2005.

Jewels and Gems in Goa from the Sixteenth to the Eighteenth Century. In: STRONGE, Susan (ed.). Jewels from India. Bombay: Marg Publications, 1995

SILVA, Nuno Vassalo; BRANCO, Aguiar. Luxo, Poder e Devoção. Jóias do séc. XVI ao séc. XIX. Porto: VOC Antiguidades, 2005.

SMITH, Marvin; GOOD, Mary Elizabeth. Early Seventeenth Century Glass Beads in the Spanish Colonial Trade. Greenwood: Cottonlandia Museum Publications, 1982.

SOCIEDADE DE ESTUDOS DE MOÇAMBIQUE, Boletim da Soc. de Estudos de Moçambique. Lourenço Marques: Edições 120-25, 1960.

SOUSA, João da Cruz e. Vestigios da lingoa arabica em Portugal: on lexicon etymologico das palabras ... Lisboa: Academia Real das Ciências, 1789.

SOUSA, Maria Teresa de Andrade e. Inventário dos bens do Conde de Vila Nova D. Luis de Lencastre 1704. Lisboa: Abril, 1956.

TAVARES, Aurea Conceição Pereira. Vestígios Materiais nos Enterramentos na Antiga Sé de Salvador: Postura das instituições religiosas africanas frente à igreja católica em Salvador no período escravista, (Dissertação apresentada ao Programa de Pós-Graduação 
em Arqueologia, para obtenção do grau de Mestre no Departamento de História do Centro de Filosofia e Ciências Humanas da Universidade Federal de Pernambuco). Pernambuco: CFCH, 2006.

TAVIM, Alberto da Silva, Judeus e cristãos-novos de Cochim. História e Memória (15001662), (prefácio de Sanjay Subrahmanyam). Braga: Edições APPACDM Distrital de Braga, 2003.

TOURNIÉ, Aurélie; PRINSLOO, Linda; COLOMBAN, Philippe. Raman Spectra Database of the Glass Beads Excavated on Mapungubwe Hill and K2, Two Archaeological Sites in South Africa. Pretoria, vol. 43, p. 532-542, Ap. 2012.

TORRES, Andreia Martins; Complementos de Vestuário da Praça Luis de Camões (Lisboa). Do Palácio Marialva no séc. XVI aos Casebres do Loreto do séc. XIX (trabalho não publicado).

TORRES, Andreia. La joyería femenina Novohispana. Continuidades y rupturas en la estética y simbología del adorno corporal. In: BAENA, Alberto y Roselló, Estela (coord.) Las mujeres en la Nueva España. México: UNAM, (no prelo).

TORRES, Andreia. Contas exumadas na intervenção arqueológica do palácio dos marqueses de Marialva - uma tipologia usada no trato colonial. Anais de História de AlémMar. Lisboa, vol. VIII, p.181-237, 2007

VASCONCELOS, José Leite de. A figa: estudo de etnografia comparativa, procedido de algumas palavras a respeito do "sobrenatural" na medicina popular portuguesa. Conferencia lida na Faculdade de Medicina do Porto em 26 de Junho de 1925. I Centenário da Régia escola de cirurgia do Porto; Porto: Araujo \& Sobrinho, sucres, 1925.

VIDALE, Massimo. Carnelian Bead Production in Khambhat, India: an Ethnoarchaeological Study. In: ALCHIN, Bridget (ed.). Living Traditions. Studies in the ethnoarcheology in South Asia. Oxford: Oxford Books, 1994.

VITERBO, Joaquim de Santa Rosa de; Elucidario das palavras, termos e frases, que em Portugal antigamente se usaram. vol. 1-2, $2^{\text {a }}$ edição. Lisboa: A. J. Fernandes Lopes, 1865.

WICKI, Joseph, GOMES, John (eds.). Documenta Indica. vol. XI (1577-1580). Roma: Andreia Martins Torres. As contas a bordo da Fragata Sto. António de TANÁ (1697) 
Institutum Historicum Societatis IESU, 1970.

WOOD, Marilee. A Glass Bead Sequence for Southern Africa from the 8th to the 16th Century AD. Journal of African Archaeology. s.1, vol. 9, n. 1, p.67-84, 2011.

Interconections. Glass Beads and trade in southern and eastern Africa and the Indian Ocean - 7th to 16th centuries AD. Studies in Global Archaeology, Sweeden, n.17, 2012.

\section{ARQUIVOS}

Boletim do Conselho Ultramarino. Lesgilação Antiga. Vol 1: 1446 a 1754. Lisboa: Imprensa Nacional, 1867, p.250

Arquivo Histórico Ultramarino (AHU), Códice 1266, Carta do feitor das Ilhas para o feitor de Moçambique, 20/2/1812, fl. 6

Archivo Historico Nacional de España (AHNE), Consejos, Libro 1521, n. ${ }^{\circ}$ 25, artigo III. Arquivo Distrital de Braga (ADB)- Convento do Carmo da Vidigueira, "Testamento de D. Miguel da Gama", maço 21, fl. 46.

Archivo General de la Nación de México (AGNM), Ind. Virreinal, caja 4957, exp.85

AGNM, Consulado, caja 5234, exp. 29

Biblioteca Nacional de Portugal, Fundo Geral, Códice 584 “História de Mombaça”, f.32r.

\section{DOCUMENTO ELECTRÓNICO}

Pretoria University, "Museums and Collections - Mapungubwe Collection" http://web.up.ac.za/default.asp?ipkCategoryID=14725\&sub=1\&parentid=10318\&subid=12 648\&ipklookid=14. Consultado a 20 de Agosto de 2013 